\title{
Springtime contribution of dinitrogen fixation to primary production across the Mediterranean Sea
}

\author{
E. Rahav ${ }^{1}$, B. Herut ${ }^{2}$, A. Levi ${ }^{1}$, M. R. Mulholland ${ }^{3}$, and I. Berman-Frank ${ }^{1}$ \\ ${ }^{1}$ Mina and Everard Goodman Faculty of Life Sciences, Bar-Ilan University, Ramat Gan 52900, Israel \\ ${ }^{2}$ Israel Oceanographic and Limnological Research, National Institute of Oceanography, Haifa 31080, Israel \\ ${ }^{3}$ Department of Ocean, Earth and Atmospheric Sciences, Old Dominion University, 4600 Elkhorn Avenue, Norfolk, \\ Virginia 23 529-0276, USA
}

Correspondence to: I. Berman-Frank (ilana.berman-frank@biu.ac.il)

Received: 6 December 2012 - Published in Ocean Sci. Discuss.: 4 January 2013

Revised: 5 April 2013 - Accepted: 5 April 2013 - Published: 14 May 2013

\begin{abstract}
Dinitrogen $\left(\mathrm{N}_{2}\right)$ fixation rates were measured during early spring across the different provinces of Mediterranean Sea surface waters. $\mathrm{N}_{2}$ fixation rates, measured using ${ }^{15} \mathrm{~N}_{2}$ enriched seawater, were lowest in the eastern basin and increased westward with a maximum at the Strait of Gibral$\operatorname{tar}\left(0.10\right.$ to $2.35 \mathrm{nmol} \mathrm{N} \mathrm{L}^{-1} \mathrm{~d}^{-1}$, respectively). These rates were 3-7 fold higher than $\mathrm{N}_{2}$ fixation rates measured previously in the Mediterranean Sea during summertime and we estimated that methodological differences alone did not account for the seasonal changes we observed. Higher contribution of $\mathrm{N}_{2}$ fixation to primary production (4-8\%) was measured in the western basin compared to the eastern basin $(\sim 2 \%)$. Our data indicates that these differences between basins may be attributed to changes in $\mathrm{N}_{2}$-fixing planktonic communities and that heterotrophic diazotrophy may play a significant role in the eastern Mediterranean while autotrophic diazotrophy has a more dominant role in the western basin.
\end{abstract}

\section{Introduction}

The Mediterranean Sea (MS) is frequently described as a "blue desert" with low phytoplankton biomass and primary production (Berman et al., 1984; Bosc et al., 2004; Ignatiades et al., 2009; Siokou-Frangou et al., 2010). The low primary production is due to the low concentration and supply of dissolved nutrients in surface waters during most of the year and this is exacerbated during spring through late fall when the water column is thermally stratified. Compounding the prob- lem, is the export of underlying, nutrient-rich intermediatedepth water to the North Atlantic Ocean through the Strait of Gibraltar (Moutin and Raimbault, 2002; Krom et al., 2010).

Dissolved inorganic nitrogen $\left(\mathrm{NO}_{3}^{-}, \mathrm{NO}_{2}^{-}, \mathrm{NH}_{4}^{+}\right)$is considered the proximate limiting nutrient for primary productivity in many oceanic regions (Falkowski, 1998), especially in low nutrient, low chlorophyll (LNLC) environments. While traditionally the MS has been considered phosphorus (P) limited (Krom et al., 1991; Thingstad et al., 1998), more recent publications demonstrate nitrogen $(\mathrm{N})$ limitation or $\mathrm{N}$ and $\mathrm{P}$ co-limitation across the two sub-basins within the MS (Thingstad et al., 2005, Tanaka et al., 2011). Diazotrophs (i.e. $\mathrm{N}_{2}$ fixers) are likely to have an advantage in $\mathrm{N}$-limited environments because they are able to utilize the abundant dissolved $\mathrm{N}_{2}$, unavailable to most organisms, as an $\mathrm{N}$ source for growth (Capone and Montoya, 2001; Zehr and Ward, 2002).

Prokaryotic dinitrogen $\left(\mathrm{N}_{2}\right)$ fixation is now recognized as a globally important input of new oceanic $\mathrm{N}$ (reviewed in Gruber, 2008) that can be subsequently transferred to other planktonic groups (Mulholland et al., 2004; Mulholland and Capone, 2009). However, reported rates of $\mathrm{N}_{2}$ fixation from the MS are limited to a few studies from the last six years and most are restricted to surface waters and the summer season. Typical rates of $\mathrm{N}_{2}$ fixation during summer from both the eastern and western basins of the MS are generally low, ranging from undetectable to $\sim 0.15 \mathrm{nmol} \mathrm{N} \mathrm{L}{ }^{-1} \mathrm{~d}^{-1}$ (Ibello et al., 2010; Ridame et al., 2011; Yogev et al., 2011; Rahav et al., 2013); however, $\mathrm{N}_{2}$ fixation rates at the central zone of the Ligurian Sea station in the NW Mediterranean (DYnamique des 


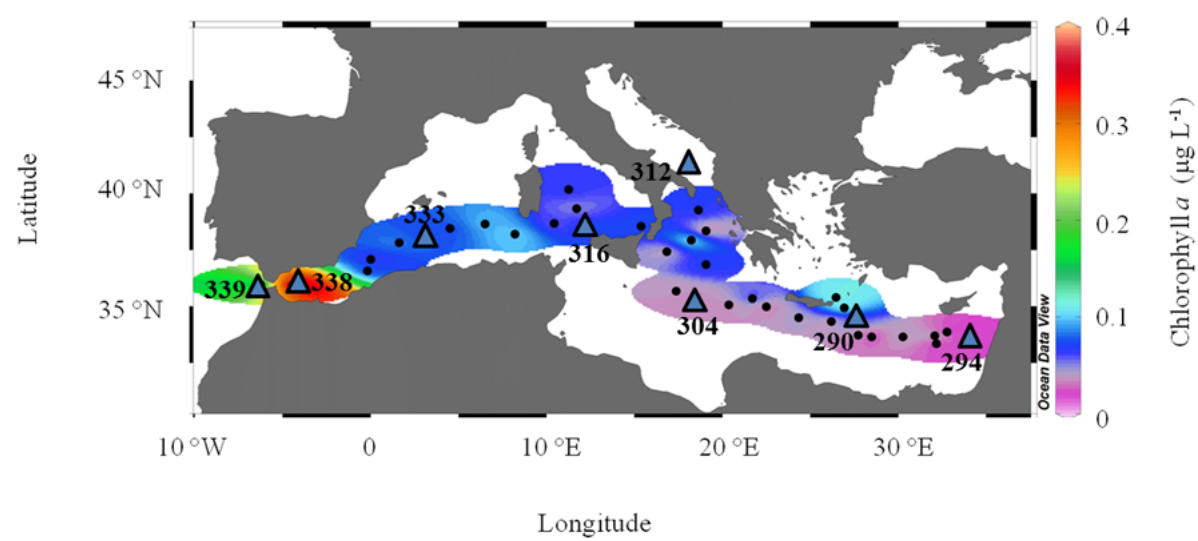

Fig. 1. Map of the sampling locations (triangles): NW Levantine basin (St. 290), anticyclonic Shikmona eddy (St. 294), Ionian Sea (St. 304), Adriatic Sea (St. 312), Tyrannian Sea (St. 316), Alboran Sea (St. 333), Strait of Gibraltar (St. 338) and Gulf of Cadiz (St. 339). Background (circle): spatial distribution of chlorophyll $a$ concentrations in surface waters $(6-8 \mathrm{~m})$ along the R/V Meteor M84/3 cruise track $(n=94)$.

Flux de mAtiére en MEDiterranée- DYFAMED) are higher ranging from 2-17 nmol $\mathrm{NL}^{-1} \mathrm{~d}^{-1}$ (Garcia et al., 2006; Sandroni et al., 2007).

Diazotrophs contributing to $\mathrm{N}_{2}$ fixation in the MS have been partially characterized (Man-Aharonovich et al., 2007; Bar Zeev et al., 2008; Le Moal and Biegala, 2009; Le Moal et al., 2011; Yogev et al., 2011). In the MS organisms expressing nifH, a gene encoding part of the nitrogenase complex, include unicellular cyanobacteria, diatom-diazotroph assemblages, proteobacteria, methanogenic archaea, anaerobic bacteria, and purple sulfur bacteria. (Man-Aharonovich et al., 2007; Yogev et al., 2011). The filamentous cyanobacterium Trichodesmium has been sporadically observed in extremely low abundances (Yogev et al., 2011); one bloom of this genus was recorded from the Aegean Sea near Lesvos Island (Spatharis et al., 2012).

The contribution of $\mathrm{N}_{2}$ fixation to new primary productivity in the MS was mostly examined during the stratified period in summer and appears to vary between the eastern and western basins. In the western basin, $\mathrm{N}_{2}$ fixation was shown to contribute up to $35 \%$ to new primary production during the stratified period (Bonnet et al., 2011), while in the Levantine basin and the eastern Mediterranean Sea (EMS), $\mathrm{N}_{2}$ fixation contributed only $\sim 0.5-2 \%$ to the new production (Yogev et al., 2011, Rahav et al., 2013). Yearly variability in the contribution of $\mathrm{N}_{2}$ fixation to new primary productivity was also observed in the DYFAMED station ranging from $1 \%$ to $28 \%$ (Sandroni et al., 2007).

Here we present $\mathrm{N}_{2}$ fixation and carbon uptake rate measurements from surface waters collected from a transect across the Mediterranean Sea during spring (before summer stratification). We calculate the contribution of diazotrophy to primary production in spring and compare these with similar measurements made during the stratified summer period to provide a more comprehensive seasonal assessment of $\mathrm{N}_{2}$ fixation in the Mediterranean Sea. Additionally, we assessed the relative contribution of heterotrophic versus autotrophic diazotrophy during springtime across the MS.

\section{Material and methods}

\subsection{Sampling locations}

This research was carried out aboard the R/V Meteor (cruise M84/3) between 4 and 28 April 2011. Eight stations were sampled along an east to west transect across the Mediterranean Sea, each representing a different water mass with associated mesoscale characteristics. Stations included: the NW Levantine basin (St. 290), the anti-cyclonic Shikmona eddy (St. 294), the Ionian Sea (St. 304), the Adriatic Sea (St. 312), the Tyrrhenian Sea (St.316), the Alboran Sea (St. 333), Strait of Gibraltar (St. 338), and the Gulf of Cadiz (St. 339) (Fig. 1 and Table 1). Seawater samples collected east of the Sicily strait were defined as eastern Mediterranean (EMS) stations, whereas samples collected to the west of Sicily strait were defined as western Mediterranean (WMS) stations. More details on the physical, chemical and biogeochemical characteristics of the water column during the cruise can be found in Tanhua et al. $(2013 a, b)$.

\subsection{Experimental design}

Subsurface seawater (6-8 $\mathrm{m}$ depth) was collected using a low pressure pump and placed in triplicate $4.6 \mathrm{~L}$ polycarbonate Nalgene bottles. $\mathrm{NaH}^{13} \mathrm{CO}_{3}$ (Sigma) was added to obtain an enrichment of approximately $1 \%$ of the ambient dissolved inorganic carbon $\left(460 \mu \mathrm{L}\right.$ of $200 \mathrm{mmol} \mathrm{L}^{-1}$ $\mathrm{NaH}^{13} \mathrm{CO}_{3}$ ) (Mulholland and Bernhardt, 2005). ${ }^{15} \mathrm{~N}_{2}$ uptake measurements were measured using a newly developed ${ }^{15} \mathrm{~N}$ enriched seawater protocol (Mohr et al., 2010). Enriched seawater was prepared by first degassing filtered $(0.2 \mu \mathrm{m})$ natural seawater collected at the same site and depth using a 
Table 1. Physical and chemical characteristics of the surface seawater (6-8 m) of the MS stations sampled during April 2011. BD- below detection limit; MLD- mixed layer depth.

\begin{tabular}{|c|c|c|c|c|c|c|c|c|}
\hline Station number & 290 & 294 & 304 & 312 & 316 & 333 & 338 & 339 \\
\hline Location & $\begin{array}{r}\text { Levantine } \\
\text { basin }\end{array}$ & $\begin{array}{r}\text { Shikmona } \\
\text { Eddy }\end{array}$ & $\begin{array}{r}\text { Ionian } \\
\text { Sea }\end{array}$ & $\begin{array}{r}\text { Adriatic } \\
\text { Sea }\end{array}$ & $\begin{array}{r}\text { Tyrrhenian } \\
\text { Sea }\end{array}$ & $\begin{array}{r}\text { Alboran } \\
\text { Sea }\end{array}$ & $\begin{array}{r}\text { Strait of } \\
\text { Gibraltar }\end{array}$ & $\begin{array}{r}\text { Gulf of } \\
\text { Cadiz }\end{array}$ \\
\hline Position & $\begin{array}{r}34^{\circ} 20^{\prime} \mathrm{N} \\
27^{\circ} 30^{\prime} \mathrm{E}\end{array}$ & $\begin{array}{l}34^{\circ} 00^{\prime} \mathrm{N} \\
34^{\circ} 25^{\prime} \mathrm{E}\end{array}$ & $\begin{array}{c}35^{\circ} 36^{\prime} \mathrm{N} \\
17^{\circ} 15^{\prime} \mathrm{E}\end{array}$ & $\begin{array}{r}41^{\circ} 15^{\prime} \mathrm{N}, \\
18^{\circ} 00^{\prime} \mathrm{E}\end{array}$ & $\begin{array}{c}38^{\circ} 36^{\prime} \mathrm{N} \\
11^{\circ} 30^{\prime} \mathrm{E}\end{array}$ & $\begin{array}{r}36^{\circ} 06^{\prime} \mathrm{N}, \\
2^{\circ} 48^{\prime} \mathrm{E}\end{array}$ & $\begin{array}{r}35^{\circ} 57^{\prime} \mathrm{N}, \\
4^{\circ} 45^{\prime} \mathrm{W}\end{array}$ & $\begin{array}{l}35^{\circ} 54^{\prime} \mathrm{N} \\
7^{\circ} 00^{\prime \prime} \mathrm{W}\end{array}$ \\
\hline Temperature $\left({ }^{\circ} \mathrm{C}\right)$ & 17.0 & 18.1 & 17.1 & 14.7 & 16.2 & 16.7 & 17.8 & 17.7 \\
\hline Salinity & 39.0 & 39.0 & 38.3 & 38.5 & 37.2 & 36.3 & 36.3 & 36.4 \\
\hline $\operatorname{MLD}(\mathrm{m})$ & 46 & 49 & 30 & 28 & 21 & 45 & 44 & 38 \\
\hline $\mathrm{NO}_{2}+\mathrm{NO}_{3}(\mu \mathrm{M})$ & $0.86 \pm 0.05$ & $0.07 \pm 0.01$ & $\mathrm{BD}$ & $0.39 \pm 0.09$ & $0.54 \pm 0.16$ & $0.63 \pm 0$ & $0.56 \pm 0.23$ & $1.39 \pm 0.84$ \\
\hline $\mathrm{PO}_{4}(\mu \mathrm{M})$ & $0.05 \pm 0.01$ & 0.05 & 0.01 & $0.02 \pm 0.02$ & $0.02 \pm 0.01$ & $0.24 \pm 0.18$ & $0.07 \pm 0.02$ & $0.06 \pm 0.03$ \\
\hline $\mathrm{Si}(\mathrm{OH})_{4}(\mu \mathrm{M})$ & $1.10 \pm 0.18$ & $0.97 \pm 0.06$ & 0.79 & $0.95 \pm 0.17$ & $0.81 \pm 0.32$ & $0.61 \pm 0.08$ & $0.48 \pm 0.13$ & $0.44 \pm 0.04$ \\
\hline
\end{tabular}

vacuum (250 mbar) applied to continuously stirred seawater for $\sim 1 \mathrm{~h}$. The degassed water was transferred into septum capped Nalgene bottles with no headspace, and $1 \mathrm{ml}$ of ${ }^{15} \mathrm{~N}_{2}$ gas $(99 \%)$ was injected per $100 \mathrm{~mL}$ of seawater. The bottles were shaken vigorously until the bubble disappeared. Aliquots of this ${ }^{15} \mathrm{~N}_{2}$-sea enriched water were then added to the incubation bottles. The enriched water constituting $5 \%$ of the total sample volume (i.e. $230 \mathrm{~mL}$ ). Similar enriched seawater additions from the oligotrophic North Pacific Subtropical Gyre (NPSG) resulted in a final ${ }^{15} \mathrm{~N}_{2}$ enrichment of 1.5 atom $\%$ after adding $50 \mathrm{~mL}$ of ${ }^{15} \mathrm{~N}_{2}$-enriched water to a 4.5 $\mathrm{L}$ bottle (Wilson et al., 2012).

After the enriched seawater and ${ }^{13} \mathrm{C}$ were added (i.e. double labeling), the bottles were well shaken, and incubated on deck at ambient surface seawater temperatures, maintained with running surface water pumped on board. Incubations began early in the morning ( $\sim 7$ a.m. local time) and the incubators were covered with either neutral density screening to simulate ambient light, or under complete darkness for $48 \mathrm{~h}$ incubations. We also compared the obtained rates with $24 \mathrm{~h}$ incubations (conducted in parallel) and obtained no significant difference between the rates $\left(R^{2}=0.91 n=24 P<\right.$ 0.05 , see Supplement Fig. S1). The incubations under ambient irradiance (representative of a full diel cycle) record the activities of both autotrophic and heterotrophic diazotrophs. Whereas, we assume that the $48 \mathrm{~h}$ dark incubations reflected the activity of mainly heterotrophic diazotrophs who do not require light energy for dinitrogen fixation. We estimated heterotrophic contribution to $\mathrm{N}_{2}$ fixation by comparing the dark incubations versus the bottles incubated under ambient diel irradiance.

Incubations were terminated by filtering water onto precombusted $25 \mathrm{~mm}$ GF/F filters (nominal pore size of $0.7 \mu \mathrm{m})$. Filters were then dried in an oven at $60^{\circ} \mathrm{C}$ and stored in a dessicator until analysis. In the laboratory, samples for ${ }^{15} \mathrm{~N}$ and ${ }^{13} \mathrm{C}$ analyses were pelletized in tin disks and then analyzed on a Europa 20/20 mass spectrometer equipped with an automated nitrogen and carbon analyzer. For isotope ratio mass spectrometry, standard curves to determine $\mathrm{N}$ and
C mass were done with each sample run. Samples were run only when standard curves had $R_{2}$ values $>0.99$. At masses $>4.7 \mu \mathrm{g} \mathrm{N}$, the precision for the atom percent ${ }^{15} \mathrm{~N}$ measurement was $0.0001 \%$ based on daily calibrations made in association with sample runs and calibrations averaged over runs made over several years. For most of the results reported here, the masses were $>4.7 \mu \mathrm{g} \mathrm{N}$. However, samples with $<4.7 \mu \mathrm{g} \mathrm{N}$ were only used if the precision was $0.0001 \%$ for that sample run. Standard masses ranged from 1.2 to $100 \mu \mathrm{g}$ $\mathrm{N}$ and from 9.4 to $800 \mu \mathrm{g}$ C. In addition to daily standard curves, reference standards and standards run as samples were run every six to eight samples.

The percent contribution of $\mathrm{N}_{2}$ fixation to primary productivity was calculated based on the measured particulate carbon (POC) and nitrogen (PON) in each sample. Although the measured POC and PON are representative of the whole planktonic community and are not specific to diazotrophs, our previous experience in the EMS suggests higher POC: PON ratio than the conventional 106: 16 Redfield ratio (Yogev et al., 2011, Rahav et al., 2013) and thus were used to calculate the $\%$ contribution.

\subsection{Physical measurements}

Measurements of temperature and salinity were taken at each station along the cruise track using an in situ conductivity, temperature and depth (CTD) sensor (Seabird 19 Plus).

\subsection{Inorganic nutrients}

Nutrient concentrations were determined for the same seawater used for the $\mathrm{N}_{2}$ fixation measurements. Duplicate water samples were collected in $15 \mathrm{~mL}$ acid-washed plastic scintillation vials from surface $(6-8 \mathrm{~m})$ using a low pressure pump (see Sect. 2.1) and immediately frozen at $-20^{\circ} \mathrm{C}$. Nutrients were determined in the laboratory $\sim 4$ months after the cruise using a segmented flow Skalar SANplus System Instrument as detailed in Kress and Herut (2001). The precision of the nitrate + nitrite, orthophosphate and silicic acid measurements were $0.02,0.003$ and $0.06 \mu \mathrm{M}$, respectively. 
Table 2. Biological characteristics of the surface seawater (6-8 m) of the MS stations sampled during April 2011.

\begin{tabular}{|c|c|c|c|c|c|c|c|c|}
\hline Parameter/station number & 290 & 294 & 304 & 312 & 316 & 333 & 338 & 339 \\
\hline $\begin{array}{l}\text { Chlorophyll } \\
\left(\mu \mathrm{g} \mathrm{L}^{-1}\right)\end{array}$ & $0.04 \pm 0.01$ & $0.03 \pm 0$ & $0.02 \pm 0.01$ & $0.11 \pm 0.03$ & $0.04 \pm 0$ & $0.18 \pm 0.01$ & $0.31 \pm 0.01$ & $0.07 \pm 0.02$ \\
\hline $\begin{array}{l}\text { Synechococcus } \\
\left(\text { cell L }{ }^{1} \text { ) }\right.\end{array}$ & $1.33 \times 10^{7}$ & $2.26 \times 10^{6}$ & $3.86 \times 10^{6}$ & $1.78 \times 10^{7}$ & $1.16 \times 10^{7}$ & $2.68 \times 10^{7}$ & $3.27 \times 10^{7}$ & $4.94 \times 10^{6}$ \\
\hline $\begin{array}{l}\text { Prochlorococcus } \\
\left(\text { cell } \mathrm{L}^{-1}\right)\end{array}$ & $1.17 \times 10^{6}$ & $8.32 \times 10^{4}$ & $3.17 \times 10^{5}$ & $1.14 \times 10^{6}$ & $1.24 \times 10^{6}$ & $2.60 \times 10^{6}$ & $1.60 \times 10^{6}$ & $3.57 \times 10^{6}$ \\
\hline $\begin{array}{l}\text { picoeukaryotes } \\
\left(\text { cell } \mathrm{L}^{-1}\right)\end{array}$ & $4.36 \times 10^{5}$ & $2.08 \times 10^{4}$ & $7.53 \times 10^{4}$ & $2.23 \times 10^{5}$ & $7.35 \times 10^{5}$ & $2.53 \times 10^{6}$ & $3.69 \times 10^{6}$ & $1.46 \times 10^{6}$ \\
\hline $\begin{array}{l}\text { Synechococcus } \\
\left(\mathrm{ng} \mathrm{C} \mathrm{L}{ }^{-1}\right)\end{array}$ & 2328 & 396 & 676 & 3115 & 2030 & 4690 & 5723 & 865 \\
\hline $\begin{array}{l}\text { Prochlorococcus } \\
\left(\mathrm{ngCL}^{-1}\right)\end{array}$ & 62 & 4 & 17 & 60 & 66 & 138 & 85 & 19 \\
\hline $\begin{array}{l}\text { pico-eukaryotes } \\
\left(\mathrm{ng} \mathrm{CL}^{-1}\right)\end{array}$ & 916 & 44 & 158 & 468 & 1544 & 5313 & 7749 & 3066 \\
\hline POC $:$ PON & $9.3 \pm 2.5$ & $9.2 \pm 0.8$ & $8.3 \pm 0.7$ & $7.6 \pm 0.7$ & $7.4 \pm 0.5$ & $8.2 \pm 1.7$ & $8.6 \pm 1.6$ & $6.4 \pm 0.3$ \\
\hline $\begin{array}{l}\text { Primary } \\
\text { productivity } \\
\left(\mu \mathrm{g} \mathrm{CL}^{-1} \mathrm{~d}^{-1}\right)\end{array}$ & $0.74 \pm 0.01$ & $0.53 \pm 0.02$ & $0.21 \pm 0.01$ & $1.39 \pm 0.87$ & $0.76 \pm 0.13$ & $0.78 \pm 0.26$ & $15.04 \pm 1.61$ & $8.01 \pm 1.79$ \\
\hline 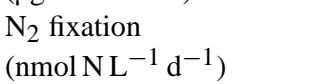 & $0.15 \pm 0.01$ & $0.12 \pm 0.02$ & $0.10 \pm 0.02$ & $0.29 \pm 0.02$ & $0.22 \pm 0.03$ & $0.86 \pm 0.17$ & $2.35 \pm 1.12$ & $0.39 \pm 0.14$ \\
\hline
\end{tabular}

The limits of quantification were $0.075 \mu \mathrm{M}, 0.008 \mu \mathrm{M}$ and $0.07 \mu \mathrm{M}$ for nitrate + nitrite, orthophosphate and silicic acid, respectively (note that for silicic acid the limit of quantification is similar to the precision). For full nutrients profiles of samples collected from Niskin bottles see Tanhua et al. (2013b).

\subsection{Chlorophyll $a$ extraction}

Duplicate seawater samples $(500 \mathrm{~mL})$ taken twice a day across the MS $(n=94)$ were filtered onto glass fiber filters. The filters were stored at $-20{ }^{0} \mathrm{C}$ in a dark box until analysis within 2-3 days. Samples were extracted in $5 \mathrm{~mL}$ $90 \%$ acetone overnight, at $4{ }^{\circ} \mathrm{C}$ in dark. Chlorophyll $a$ (Chl $a$ ) concentrations were determined with a Turner Designs (TD-700) fluorometer, using a $436 \mathrm{~nm}$ excitation filter and a $680 \mathrm{~nm}$ emission filter (Holm-Hansen, 1965). A blank filter was also stored in $90 \%$ acetone under the same conditions as the samples.

\subsection{Picophytoplankton abundance}

The abundance of picophytoplankton was determined by flow cytometry. Taxonomic discrimination was based on the following parameters: cell side scatter - a proxy of cell volume; forward scatter - a proxy of cell size; and orange and red fluorescence of phycoerythrin and of chlorophyll $a$ (585 $\mathrm{nm}$ and $630 \mathrm{~nm}$, respectively). Samples of $1.8 \mathrm{~mL}$ were fixed immediately at room temperature with $23 \mu \mathrm{L}$ of $25 \%$ gluteraldehyde (Sigma G-5882) retained at room temperature for $10 \mathrm{~min}$, subsequently frozen in liquid nitrogen, and kept at $-80^{\circ} \mathrm{C}$ until analyzed. Samples were fast thawed at $37^{\circ} \mathrm{C}$, and counted using a FACScan Becton Dickinson flow cytometer, fitted with an Argon laser $(488 \mathrm{~nm})$ for 10 to $15 \mathrm{~min}$ or until 30000 cells were counted (Vaulot et al., 1989). Pico/nano phytoplankton carbon (C) biomass was calculated from cell counts assuming $175 \mathrm{fg} \mathrm{C}^{-1} \mathrm{Cll}^{-1}$ for Synechococcus cells $53 \mathrm{fg} \mathrm{C}$ cell $^{-1}$ for Prochlorococcus cells, and $2100 \mathrm{fg}$ $\mathrm{C}$ cell $^{-1}$ for pico-eukaryotes (Campbell and Yentsch, 1989).

\section{Results}

\subsection{East-west distribution of physical, chemical and phytoplankton parameters}

The physical, chemical and biological parameters of the surface waters at each station are provided in Tables 1 and 2 . Overall, surface temperatures and salinities increased from west to east from 14.7 to $18.1^{\circ} \mathrm{C}$ and 36.3 to 39 , respectively. $\mathrm{NO}_{2}^{-}+\mathrm{NO}_{3}^{-}$(DIN) increased from east to west from below detection in the Ionian Sea to $1.39 \mu \mathrm{M}$ at the Gulf of Cadiz station (Table 1). In contrast, Station 290 (NW Levantine Basin) had high surface concentrations of DIN $(0.86 \mu \mathrm{M})$, probably due to upwelling of deeper waters within the cyclonic Rhodes Gyre. Dissolved inorganic phosphorus (DIP) ranged from 0.01 to $0.24 \mu \mathrm{M}$ in surface waters across the entire Mediterranean Sea (MS) (Table 1). Silicic acid $\left(\mathrm{Si}(\mathrm{OH})_{4}\right)$ concentration was lowest in the westernmost stations - at the entrance to the MS $(0.44 \mu \mathrm{M})$, and increased toward the east with highest concentration observed at the easternmost station $(1.10 \mu \mathrm{M})$ (Table 1$)$. 

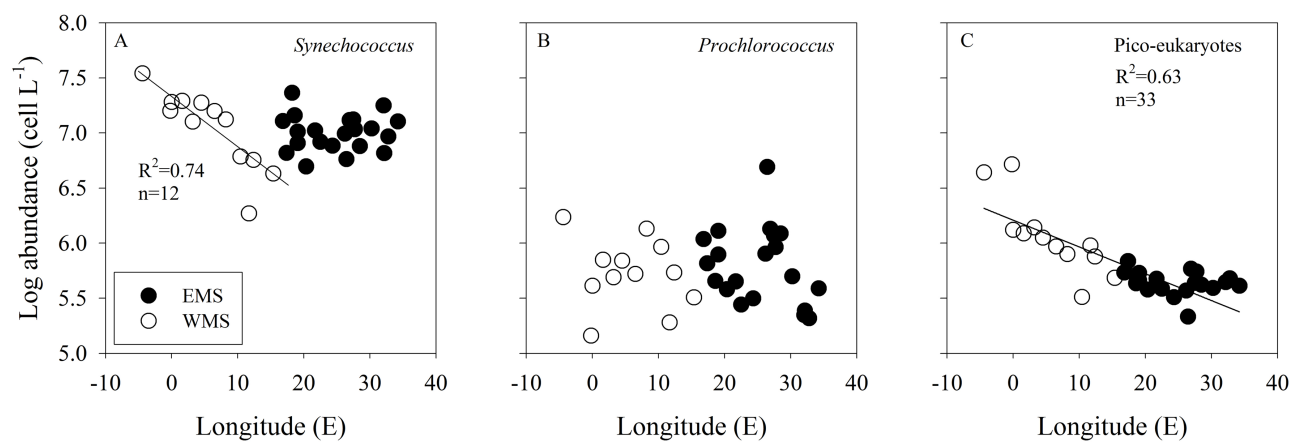

Fig. 2. Picophytoplankton distribution of Synechococcus (A), Prochlorococcus (B) and pico-eukaryotes (C) in the surface waters (6-8 m) of the eastern (black circle) and western (white circle) Mediterranean Sea. $n=21$ and $n=12$ for the eastern and western basins, respectively.

Chlorophyll (Chl $a$ ) concentrations increased from east to west across the MS. Surface Chl $a$ concentrations were $\sim 0.03 \mu \mathrm{gL}^{-1}$ at the eastern basin stations and up to $0.31 \mu \mathrm{g} \mathrm{L}-1$ at the Strait of Gibraltar - the westernmost station (Fig. 1). Synechococcus dominated the picophyto-

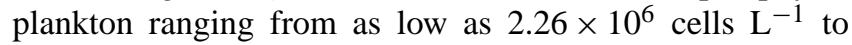
$3.27 \times 10^{7}$ cells $\mathrm{L}^{-1}$ in the eastern and western basin, respectively (Fig. 2, Table 2). Using a cell : carbon conversion ratio of $175 \mathrm{fg} \mathrm{C}^{-1}{ }^{-1}$ (see methods), this represents a range of $396 \mathrm{ng} \mathrm{C} \mathrm{L}^{-1}$ to $5723 \mathrm{ng} \mathrm{CL}^{-1}$. In the eastern basin, the picoeukaryote abundances $\left(\sim 2.1 \times 10^{4}\right.$ to $7.5 \times 10^{4}$ cell L $\left.^{-1}\right)$ and biomass (44 to $158 \mathrm{ng} \mathrm{CL}^{-1}$ ) were low except in the Levantine basin (Station 290) where higher abundances $\left(4.36 \times 10^{5}\right.$ cell L $\left.^{-1}\right)$ and biomass $\left(916 \mathrm{ng} \mathrm{C} \mathrm{L}^{-1}\right)$ were measured (Fig. 2, Table 2). Prochlorococcus abundances and biomass from the surface waters were generally low throughout the whole MS, especially at the Shikmona Eddy (Station 294) and the Ionian Sea (station 304) (Fig. 2, Table 2).

\subsection{Primary productivity and $\mathrm{N}_{2}$ fixation rates}

Photosynthetic carbon fixation rates ranged from 0.21 to $0.74 \mu \mathrm{g} \mathrm{CL}^{-1} \mathrm{~d}^{-1}$ in the eastern basin, and 0.76 to $1.39 \mu \mathrm{g}$ $\mathrm{CL}^{-1} \mathrm{~d}^{-1}$ at the western Mediterranean stations. Much higher rates were measured at the Strait of Gibraltar $\left(15.04 \pm 1.6 \mu \mathrm{g} \mathrm{C} \mathrm{L}-1 \mathrm{~d}^{-1}\right)$ and in the Gulf of Cadiz $(8.22 \mu \mathrm{g}$ $\mathrm{CL}^{-1} \mathrm{~d}^{-1}$ ) (Table 2).

$\mathrm{N}_{2}$ fixation rates obtained across the MS exhibited a strong zonal gradient from the eastern to western basins (Fig. 3a and Table 2). The lowest $\mathrm{N}_{2}$ fixation rates were measured in the eastern basin, ranging from $0.10 \pm 0.02 \mathrm{nmol} \mathrm{N} \mathrm{L}^{-1} \mathrm{~d}^{-1}$ in the Ionian Sea, to $0.15 \pm 0.01 \mathrm{nmol} \mathrm{N} \mathrm{L}^{-1} \mathrm{~d}^{-1}$ at Station 290 (affected by the Rhodes Gyre) (Fig. 3a and Table 2). $\mathrm{N}_{2}$ fixation rates increased gradually toward the west ranging from $0.22 \pm 0.03$ in the Tyhrranean Sea to $2.35 \pm 1.12 \mathrm{nmol}$ $\mathrm{NL}^{-1} \mathrm{~d}^{-1}$ at the westernmost station at the Strait of Gibral$\operatorname{tar}$ (Fig. 3a and Table 2). The springtime rates of $\mathrm{N}_{2}$ fixation at all stations were 3-7 fold higher than measurements published previously during summertime (Fig. 3b).
In addition to total $\mathrm{N}_{2}$ fixation (measured in light bottles under ambient diel irradiance), we examined $\mathrm{N}_{2}$ fixation rates in bottles incubated for $48 \mathrm{~h}$ in the dark. While some unicellular cyanobacteria fix $\mathrm{N}_{2}$ during the dark hours, they require light energy to fuel the process. We assumed that after $48 \mathrm{~h}$ in the dark, the contribution by these diazotrophs will be negligible and most $\mathrm{N}_{2}$ fixation would be due to heterotrophic diazotrophs that do not require light for the $\mathrm{N}_{2}$ fixing process (Postage, 1979). The $\mathrm{N}_{2}$ fixation rates from $48 \mathrm{~h}$ dark incubations showed a similar east-west trend as observed in light bottle incubations (Fig. 4a); within the eastern basin, $\mathrm{N}_{2}$ fixation in dark incubations were lowest at the easternmost Station $290\left(0.11 \pm 0.02 \mathrm{nmol} \mathrm{NL}^{-1} \mathrm{~d}^{-1}\right)$ and highest at Station 294 in the Shikmona Eddy $(0.16 \pm 0.01 \mathrm{nmol}$ $\mathrm{NL}^{-1} \mathrm{~d}^{-1}$ ) (Figure 4A). In the western basin $\mathrm{N}_{2}$ fixation rates in dark incubation bottles rates ranged from $0.20 \pm 0.05$ to $0.40 \pm 0.11 \mathrm{nmol} \mathrm{N} \mathrm{L}^{-1} \mathrm{~d}^{-1}$ (Fig. 4a).

We compared rates of light and dark $\mathrm{N}_{2}$ fixation (Fig. 4b) to estimate the relative contribution of autotrophic versus heterotrophic $\mathrm{N}_{2}$ fixation. In the western basin, light : dark estimates of $\mathrm{N}_{2}$ fixation were always $>1$, suggesting the predominance of autotrophic $\mathrm{N}_{2}$ fixation. In the eastern basin light: dark $\mathrm{N}_{2}$ fixation rates were $<1$ suggesting a preponderance of heterotrophic diazotrophs (Fig. 4).

\subsection{The contribution of $\mathrm{N}_{2}$ fixation to primary produc- tivity}

We calculated the percent contribution of $\mathrm{N}_{2}$ fixation to total primary productivity during springtime based on rates of $\mathrm{N}_{2}$ fixation measured in the light bottle incubations and the associated $\mathrm{C}$ fixation estimated using an the average particulate $\mathrm{C}: \mathrm{N}$ ratio obtained at each station (Table 2, and see Yogev et al., 2011; Rahav et al., 2013). New production due to $\mathrm{N}_{2}$ fixation was $\sim 2 \%$ of the total primary productivity at the EMS stations and increased by a factor of 2 to 4 in the western Mediterranean Sea (WMS), ranging from $3.5 \%$ in the Adriatic Sea to $8.5 \%$ in the Alboran Sea. The percent contribution of $\mathrm{N}_{2}$ fixation to primary production in the Gulf of 


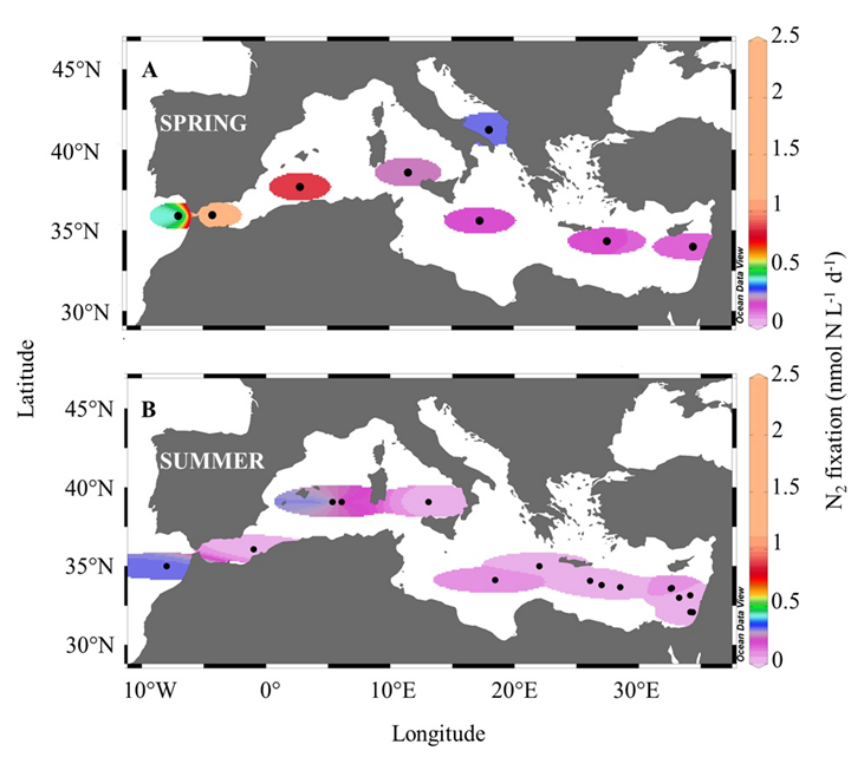

Fig. 3. Seasonal variations of $\mathrm{N}_{2}$ fixation in the surface waters of the Mediterranean Sea. (A) Springtime rates measured in this study. (B) Summer data compiled from Rahav et al., 2013; Yogev et al., 2011; Ibello et al., 2010; Bonnet et al., 2011.

Cadiz, near the Strait of Gibraltar that connects the Mediterranean Sea with the Atlantic Ocean, was $2.3 \%$ (Fig. 5).

\section{Discussion}

This study provides the first springtime measurements of $\mathrm{N}_{2}$ fixation in surface waters along an east-west transect across the Mediterranean Sea (MS). We focused sampling at representative stations from different water provinces in the MS (Fig. 1, Table 1). Our results yielded $\mathrm{N}_{2}$ fixation rates in surface waters that are 3-7 fold higher (Fig. 3a, Table 2) than published rates from two summertime basin-wide $\mathrm{N}_{2}$ fixation studies (Ibello et al., 2010; Bonnet et al., 2011), routine stations off the Israeli coast (Yogev et al., 2011), and a Levantine Basin transect (Rahav et al., 2013). Moreover, the gradient of increasing $\mathrm{N}_{2}$ fixation rates from east to west coincide with the east-west gradient in surface Chl $a$ (Fig. 1) and primary productivity (Table 2 ).

Seasonal measurements of $\mathrm{N}_{2}$ fixation rates in the MS have been made at two monitoring stations, one located west of the Israeli coastline (Levantine Basin) (Yogev et al., 2011) and the other off the coast of France, the DYFAMED station (Ligurian Sea) (Garcia et al., 2006; Sandroni et al., 2007). Rates of $\mathrm{N}_{2}$ fixation in surface waters from the Levantine Basin were uniformly low $\left(\sim 0.01 \mathrm{nmol} \mathrm{N} \mathrm{L}^{-1} \mathrm{~d}^{-1}\right)$ and did not show any seasonality (Yogev et al., 2011). In contrast, at the WMS time series station (DYFAMED), higher rates of $\mathrm{N}_{2}$ fixation were measured during April and August (4-7.5 nmol $\mathrm{NL}^{-1} \mathrm{~d}^{-1}, 10 \mathrm{~m}$ ) relative to other months $\left(<2\right.$ nmol $\left.\mathrm{NL}^{-1} \mathrm{~d}^{-1}, 10 \mathrm{~m}\right)$, which were associated with higher primary productivity rates (Sandroni et al., 2007).

The Shikmona Eddy (Station 294) and the Ionian Sea (Station 304), representing ultraoligotrophic conditions, had lower nutrient and $\mathrm{Chl} a$ concentrations than the more productive cyclonic Rhodes Gyre station (Station 290). Yet similar $\mathrm{N}_{2}$ fixation rates were measured at all three stations (Fig. 3a, Table 2) and there was no correlation between $\mathrm{N}_{2}$ fixation and primary production $\left(R^{2}=0.18\right.$, $n=9, t$ test, $P>0.05)$. This suggests that $\mathrm{N}_{2}$ fixation is attributed mainly to heterotrophic bacteria or that diazotrophs and nondiazotrophic phytoplankton are limited or co-limited by different nutrients. Heterotrophic bacteria are known to compete for $\mathrm{N}$ with autotrophs in the nutrientdepleted surface waters of the EMS (Thingstad et al., 2005; Tanaka et al., 2007) and molecular fingerprinting suggests a highly diverse heterotrophic community of nifH phylotypes (Man-Aharonovich et al., 2007; Yogev et al., 2011). Heterotrophic diazotrophs may outcompete other bacteria in an $\mathrm{N}$-impoverished system because they can acquire $\mathrm{N}$ from the abundant $\mathrm{N}_{2}$ pool. Evidence for heterotrophic diazotrophy was found in both surface and aphotic depths in the EMS (Rahav et al., 2013).

Higher DIN (Table 1) and Chl $a$ concentrations were measured in the more productive WMS compared to the EMS (Fig. 1, Table 2). Concurrently, $\mathrm{N}_{2}$ fixation rates in the WMS were also higher (ANOVA, $P<0.05$ ) ranging from 0.22 to $0.86 \mathrm{nmol} \mathrm{N} \mathrm{N}^{-1} \mathrm{~d}^{-1}$ (Fig. 3a, Table 2) and correlated with PP $\left(R^{2}=0.82, n=12, t\right.$ test, $\left.P<0.05\right)$, suggesting photoautotrophic associated $\mathrm{N}_{2}$ fixation. Indeed, relatively high diatom abundances were detected in surface waters of the WMS ( $>100$ cells $\mathrm{L}^{-1}$ ) associated with a small spring bloom (A. Oviedo, personal communication, 2013). Richelia intracellularis, a symbiotic $\mathrm{N}_{2}$ fixing cyanobacterium, has been found associated with diatoms in the EMS previously (Bar-Zeev et al., 2008) and may have contributed to $\mathrm{N}_{2}$ fixation in the WMS.

The highest $\mathrm{N}_{2}$ fixation rates during this spring transect were observed at the westernmost station in the Strait of Gibraltar (Fig. 3a, Table 2). Moreover, these springtime $\mathrm{N}_{2}$ fixation rates were 7-fold higher than those measured previously during summer by Ibello et al. (2010) ( $2.35 \mathrm{nmol} \mathrm{N} \mathrm{L} \mathrm{d}^{-1} \mathrm{~d}^{-1}$ vs. $0.3 \mathrm{nmol} \mathrm{N} \mathrm{L}{ }^{-1} \mathrm{~d}^{-1}$, respectively). These differences suggest seasonality of $\mathrm{N}_{2}$ fixation and/or the abundance or activity of diazotrophic populations, or seasonal exchange of water and resident planktonic populations between the eastern Atlantic Ocean and the MS through the Strait of Gibraltar.

During this study $\mathrm{N}_{2}$ fixation rates were only measured in surface waters (upper 6-8 m) and therefore depth-integrated $\mathrm{N}_{2}$ fixation rates could not be calculated. It is therefore conceivable that many autotrophic and heterotrophic diazotrophic groups populating other depths, such as the deep Chl $a$ maximum (DCM), were not accounted for in our rate measurements. In addition, seasonal changes in the vertical 

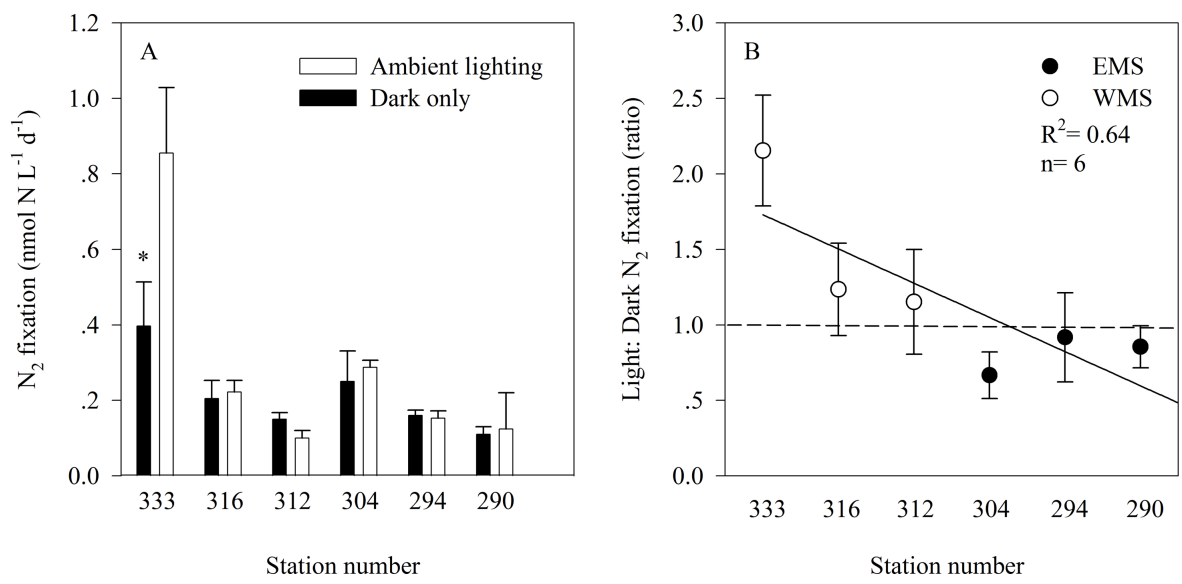

Fig. 4. (A) $\mathrm{N}_{2}$ fixation rates of surface waters from stations across the Mediterranean Sea for bottles incubated under ambient lighting (white bars) and in complete darkness (dark bars). The asterisk above the columns represents statistically significant differences (one-way ANOVA, $P<0.05$ ) for mean values of $\mathrm{N}_{2}$ fixation rates in each station, and (B) the resulting ratio between rates of $\mathrm{N}_{2}$ fixation from ambient lighting and dark incubations. $n=3$ for each incubation type at each station.

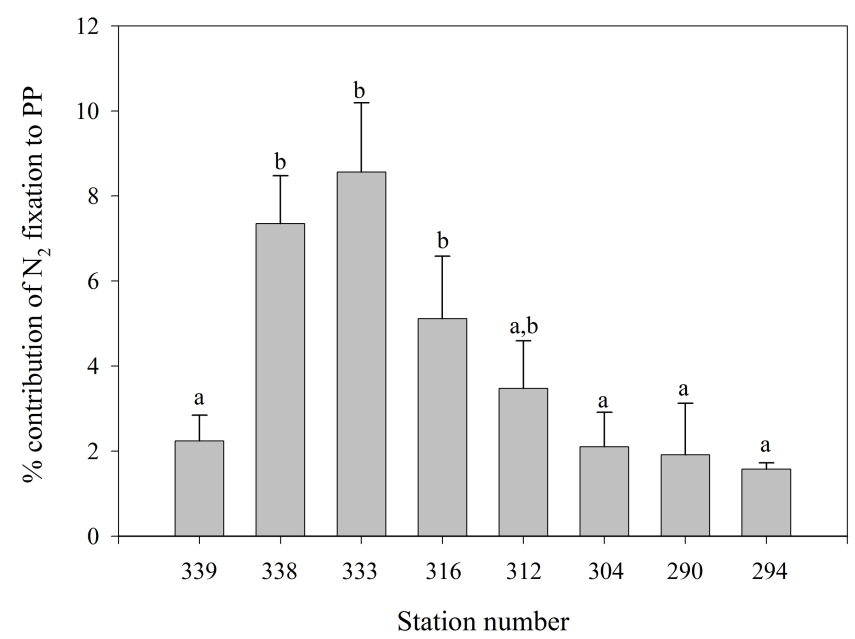

Fig. 5. The percent contribution of $\mathrm{N}_{2}$ fixation to primary productivity (PP) of surface waters sampled across the MS during the spring period. The letters above the columns represent statistically significant differences (one-way ANOVA and a Fisher LSD means comparison test, $P<0.05$ ) for mean values of $\%$ contribution between stations.

distribution of diazotrophic microbes were not considered here. For example, a recent study from the eastern basin found no statistical difference in $\mathrm{N}_{2}$ fixation rates measured in water collected from below the pycnocline at the DCM compared to surface waters during the stratified period, while during the winter mixing period, when the water column was mixed up to $150 \mathrm{~m}$, the $\mathrm{N}_{2}$ fixation rates were 2-3 fold higher at the DCM than in surface waters (Yogev et al., 2011).

Another methodological contribution to the higher $\mathrm{N}_{2}$ fixation rates during spring throughout the MS was our use of the newly enriched $\left({ }^{15} \mathrm{~N}_{2}\right)$ seawater addition method (Mohr et al., 2010) rather than the gas bubble ${ }^{15} \mathrm{~N}_{2}$ addition method (Montoya et al., 1996). The gas bubble enrichment method may underestimate $\mathrm{N}_{2}$ fixation rates by a factor of 2 or more in some circumstances (Großkopf et al., 2012; Wilson et al., 2012). Our preliminary comparison of both methods in MS waters demonstrated a 2-3 fold increase in rates using the enriched seawater method $(n=18)$. However, in long incubations ( $>24 \mathrm{~h}$ ), the underestimate of $\mathrm{N}_{2}$ fixation using the bubble method was reduced because the gas bubble should have equilibrated within the first several hours of the incubation (Mohr et al., 2010; Mulholland et al., 2012). While it is impossible to convert from one method to another using a constant conversion factor, if we assume a two-fold underestimate of previously reported summer $\mathrm{N}_{2}$ fixation rates, we still observe significant seasonal differences in $\mathrm{N}_{2}$ fixation rates between the early spring and fully stratified summer periods. This suggests that methodological differences alone cannot account for the seasonal changes we observed.

We examined the relative contribution of autotrophic and heterotrophic diazotrophs to the measured $\mathrm{N}_{2}$ fixation rates using parallel natural light and dark bottle incubations. It has generally been assumed that diazotrophy in surface waters is dominated by photoautotrophic cyanobacteria that use light energy to satisfy the energetic demands of $\mathrm{N}_{2}$ fixation and to acquire carbon (Karl et al., 2002). Yet, research demonstrates that the abundant and widely distributed unicellular group A cyanobacteria are photoheterotrophs (Zehr et al., 2008; Tripp et al., 2010). Further, many heterotrophic diazotrophs are present in surface waters (Riemann et al., 2010; Zehr and Kudela, 2011; Mulholland et al., 2012). Our results show that in the eastern basin stations, the ratio of light : dark bottle $\mathrm{N}_{2}$ fixation was usually $<1$ (Fig. 4b) suggesting that heterotrophic diazotrophs may be the dominant $\mathrm{N}_{2}$ fixers, although we cannot exclude that some of the 
dark $\mathrm{N}_{2}$ fixation was performed by unicellular cyanobacteria. In the western basin, this ratio was generally $>1$ suggesting that autotrophic diazotrophs predominated (Fig. 4b). We acknowledge that some phototrophic diazotrophs fix $\mathrm{N}_{2}$ during the dark, to avoid the inhibitory effects of oxygen, but we assume that our long incubation time in the dark (48 h) would have diminished their impact as they require light energy to fix $\mathrm{N}_{2}$.

Phylogenetic characterizations of diazotrophs in surface waters across this Mediterranean transect are currently unavailable. However, a diverse group of auto- and heterotrophic diazotrophs have been reported from the eastern basin with $\sim 40 \%$ of the nifH transcripts attributed to heterotrophic bacteria (Man-Aharonovich et al., 2007; BarZeev et al., 2008; Yogev et al., 2011). In the WMS, unicellular cyanobacteria (including UCYN-A) are present in low abundances year round and short blooms of 2000-5000 cells $\mathrm{mL}^{-1}$ have been reported from a coastal station off Marseille during June and July (Le Moal and Biegala, 2009). Another recent study suggested that cells $<0.7 \mu \mathrm{m}$ in size, usually ignored during routine sampling, can contribute $50 \%$ of the $\mathrm{N}_{2}$ fixation (Konno et al., 2010). In this study we used GF/F filters to measure planktonic $\mathrm{N}_{2}$ fixation (nominal pore size of $\sim 0.7 \mu \mathrm{m}$, see methods), as is a common practice. Thus, it is possible we could have missed $\mathrm{N}_{2}$ fixation by very small bacteria diazotrophs and thereby underestimated total planktonic $\mathrm{N}_{2}$ fixation.

Based on results from studies conducted during summer in the EMS, $\mathrm{N}_{2}$ fixation accounted for only $0.7-2 \%$ of primary productivity at stations in the Levantine basin (Yogev et al., 2011, Rahav et al., 2013), but increased to $\sim 6 \%$ in the more productive Rhodes Gyre and Cyprus Eddy (Rahav et al., 2013). Consistent with these results, during a summer transect across the Mediterranean (BOUM campaign), $\mathrm{N}_{2}$ fixation accounted for 6 to $35 \%$ of new production at stations in the more productive western basin but only 0 to $0.3 \%$ at the more oligotrophic eastern basin (Bonnet et al., 2011). Our springtime results show higher $\mathrm{N}_{2}$ fixation rates (2-4 fold) at both basins and a similar spatial trend. A higher contribution of $\mathrm{N}_{2}$ fixation to primary production (4-8\%) was measured in the western basin compared to the eastern basin ( $\sim 2 \%$, Fig. 5). These differences between the two basins are probably attributed to changes in $\mathrm{N}_{2}$-fixing planktonic communities and other environmental aspects. Summertime data from the EMS demonstrated a significant positive correlation between $\mathrm{N}_{2}$ fixation rates and bacterial production suggesting a higher involvement of heterotrophic diazotrophs in the ultraoligotrophic EMS (Rahav et al., 2013).

\section{Conclusions}

This study provides the first direct measurements of $\mathrm{N}_{2}$ fixation rates in surface waters across the MS during springtime. $\mathrm{N}_{2}$ fixation rates were measured using the newly modified
${ }^{15} \mathrm{~N}_{2}$-uptake method (Mohr et al., 2010) during a spring transect and were 3-7 fold higher than measurements made in surface waters during the stratified summer period. Methodological differences cannot fully account for the higher rates of $\mathrm{N}_{2}$ fixation observed during this cruise and we suggest that the higher rates are due to seasonal variability in primary productivity and environmental factors. $\mathrm{N}_{2}$ fixation was higher and contributed more to total primary production in the western basin than in the eastern basin. While our data suggests that $\mathrm{N}_{2}$ fixation rates across the MS are higher during spring than in the summer stratified period, our measurements were constrained to surface waters and thus we cannot provide depth integrated estimates of $\mathrm{N}_{2}$ fixation during spring. We suggest that future investigations should include $\mathrm{N}_{2}$ fixation rate measurements and phylogenetic identity of diazotrophs at both photic and aphotic depths to better constrain the contribution of $\mathrm{N}_{2}$ fixation to $\mathrm{N}$ budgets as well as the total and new production within the Mediterranean Sea.

\section{Supplementary material related to this article is available online at: http://www.ocean-sci.net/9/489/2013/ os-9-489-2013-supplement.pdf.}

Acknowledgements. Many thanks for the help provided by the captain and crew of the R/V Meteor. We would also like to thank Toste Tanhua, the Chief Scientist of this cruise, for allowing us to take part in this campaign. This research was supported by the Israel Science Foundation grant (996/08) to I. B-F and B. H. This study is in partial fulfillment of a Ph.D. thesis for Eyal Rahav from Bar Ilan University.

Edited by: T. Tanhua

\section{References}

Bar Zeev, E., Yogev, T., Man-Aharonovich, D., Kress, N., Herut, B., Beja, O., and Berman-Frank, I.: Seasonal dynamics of the endosymbiotic, nitrogen-fixing cyanobacterium Richelia intracellularis in the Eastern Mediterranean Sea, ISME J., 2, 911-92. 2008.

Berman, T., Townsend, D. W., Elsayed, S. Z., Trees, C. C., and Azov, Y.: Optical transparency, chlorophyll and primary productivity in the Eastern Mediterranean near the Israeli coast, Oceanol. Acta., 7, 367-372, 1984.

Bonnet, S., Grosso, O., and Moutin, T.: Planktonic dinitrogen fixation along a longitudinal gradient across the Mediterranean Sea during the stratified period (BOUM cruise), Biogeosciences, 8 , 2257-2267, doi:10.5194/bg-8-2257-2011, 2011.

Bosc, E., Bricaud, A., and Antoine, D.: Seasonal and interannual variability in algal biomass and primary production in the Mediterranean Sea, as derived from 4 years of SeaWiFS observations, Global Biogeochem. Cy., 18, GB1005, doi:10.1029/2003GB002034, 2004. 
Campbell, J. W. and Yentsch, C. M.: Variance within homogeneous phytoplankton populations .1. Theoretical framework for interpreting histograms, Cytometry, 10, 587-595, 1989.

Capone, D. G. and Montoya, J. P.: Nitrogen fixation and denitrification, Methods Microbiol., 30, 501-51, 2001.

Falkowski, P. G., Barber, R. T., and Smetacek, V.: Biogeochemical controls and feedbacks on ocean primary production, Science, 281, 200-206, 1998.

Garcia, N., Raimbault, P., Gouze E., and Sandroni, V.: Nitrogen fixation and primary production in Western Mediterranean, Comptes. Rendus. Biologies., 329, 742-750, 2006.

Großkopf, T., Mohr, W., Baustian, T., Schunck, H., Gill, D., Kuypers, M. M. M., Lavik, G., Schmitz, R. A., Wallace, D. W. R., and LaRoche, J.: Doubling of marine dinitrogen-fixation rates based on direct measurements, Nature, 488, 361-364, 2012.

Gruber, N.: The marine nitrogen cycle: Overview of distributions and processes, in: Nitrogen in the marine environment, edited by: Capone, D., Bronk, D., Mulholland, M., and Carpenter, E., Elsevier, Amsterdam, 1-50, 2008.

Holm-Hansen, O., Lorenzen, C. J., Homes, R. W., and Strickland, J. D. H.: Fluorometric determination of chlorophyll., Journal du Conseil Permanent Internationale pour L'Exploration de la Mer., 30, 2-15, 1965.

Ibello, V., Cantoni, C., Cozzi, S., and Civitarese, G.: First basin-wide experimental results on $\mathrm{N}_{2}$ fixation in the open Mediterranean Sea, Geophys. Res. Lett., 37, L03608, doi:10.1029/2009GL041635, 2010.

Ignatiades, L., Gotsis-Skretas, O., Pagou, K., and Krasakopoulou, E.: Diversification of phytoplankton community structure and related parameters along a large-scale longitudinal east-west transect of the Mediterranean Sea, J. Plankton. Res., 31, 411-428, 2009.

Karl, D., Michaels, A., Bergman, B., Capone D., Carpenter, E., Letelier, R., Lipschultz, F., Paerl, H., Sigman, D., and Stal, L.: Dinitrogen fixation in the world's oceans, Biogeochemistry, 57, 47-98, 2002.

Konno, U., Tsunogai, U., Komatsu, D. D., Daita, S., Nakagawa, F., Tsuda, A., Matsui, T., Eum, Y.-J., and Suzuki, K.: Determination of total $\mathrm{N}_{2}$ fixation rates in the ocean taking into account both the particulate and filtrate fractions, Biogeosciences, 7, 2369-2377, doi:10.5194/bg-7-2369-2010, 2010.

Kress, N. and Herut, B.: Spatial and seasonal evolution of dissolved oxygen and nutrients in the Southern Levantine Basin (Eastern Mediterranean Sea): chemical characterization of the water masses and inferences on the N : P ratios, Deep-Sea Res. Pt. I, 48, 2347-2372, 2001.

Krom, M. D., Brenner, S., Kress, N., and Gordon, L. I.: Phosphorous limitation of primary productivity in the Eastern Mediterranean Sea, Limnol. Oceanogr., 36, 424-43, 1991.

Krom, M. D., Emeis, K. C., and Van Cappellen, P.: Why is the Eastern Mediterranean phosphorus limited?, Prog. Oceanogr., 85, 236-244, 2010.

Le Moal, M., and Biegala, I. C.: Diazotrophic unicellular cyanobacteria in the Northwestern Mediterranean Sea: A seasonal cycle, Limnol. Oceanogr., 54, 845-855, 2009.

Le Moal, M., Collin, H., and Biegala, I. C.: Intriguing diversity among diazotrophic picoplankton along a Mediterranean transect: a dominance of rhizobia, Biogeosciences, 8, 827-840, doi:10.5194/bg-8-827-2011, 2011.
Man-Aharonovich, D., Kress, N., Bar Zeev, E., Berman-Frank, I., and Beja, O.: Molecular ecology of nifH genes and transcripts in the Eastern Mediterranean Sea, Environ. Microbiol., 9, 2354236, 2007.

Moisander, P. H., Beinart, R. A., Hewson, I., White, A. E., Johnson, K. S., Carlson, C. A., Montoya, J. P., and Zehr, J. P.: Unicellular cyanobacterial distributions broaden the oceanic $\mathrm{N}_{2}$ fixation domain, Science, 327, 1512-1514, 2010.

Mohr, W., Grosskopf, T., Wallace, D. W. R., and LaRoche, J.: Methodological underestimation of oceanic nitrogen fixation rates, PloS One, 5, e12583. doi:10.1371/journal.pone.0012583, 2010.

Montoya, J. P., Voss, M., Kahler, P., and Capone, D. G.: A simple, high-precision, high-sensitivity tracer assay for N2 fixation, Appl. Environ. Microbiol., 62, 986-993, 1996.

Moutin, T. and Raimbault, P.: Primary production, carbon export and nutrients availability in western and eastern Mediterranean Sea in early summer 1996 (MINOS cruise), J. Marine. Syst., 33, 273-288, 2002.

Mulholland, M. R., Boneillo, G., and Minor, E. C.: A comparison of $\mathrm{N}$ and $\mathrm{C}$ uptake during brown tide (Aureococcus anophagefferens) blooms from two coastal bays on the east coast of the USA, Harmful Algae, 3, 361-376, 2004.

Mulholland, M. R. and Capone, D. G.: Dinitrogen fixation in the Indian Ocean, in: Indian Ocean Biogeochemical Processes and Ecological Variability, edited by: Wiggert, J. D., Hood, R. R., Naqvi, S. W. A., Brink, K. H., and Smith, S. L., American Geophysical Union, Washington, DC, 167-186, 2009.

Mulholland, M. R. and Bernhardt, P. W.: The effect of growth rate, phosphorus concentration, and temperature on $\mathrm{N}_{2}$ fixation, carbon fixation, and nitrogen release in continuous cultures of Trichodesmium IMS101, Limnol. Oceanogr., 50, 839-849, 2005.

Postgate, J.: Nitrogen-fixation and the future of the worlds foodsupply, Biologist, 26, 165-166, 1979.

Rahav, E., Herut, B., Stambler, N., Bar Zeev, E., Mulholland, M. R., and Berman-Frank, I.: Uncoupling between dinitrogen fixation and primary productivity in the Eastern Mediterranean Sea, J. Geophys. Res-Biogeo., 118, 1-8, doi:10.1002/jgrg.20023, 2013.

Ridame, C., Le Moal, M., Guieu, C., Ternon, E., Biegala, I. C., L'Helguen, S., and Pujo-Pay, M.: Nutrient control of N2 fixation in the oligotrophic Mediterranean Sea and the impact of Saharan dust events, Biogeosciences, 8, 2773-2783, doi:10.5194/bg8-2773-2011, 2011.

Riemann, L., Farnelid, H., and Steward, G. F.: Nitrogenase genes in non-cyanobacterial plankton: prevalence, diversity and regulation in marine waters, Aquat. Microb. Ecol., 61, 225-237, 2010.

Sandroni, V., Raimbault, P., Migon, C., Garcia, N., and Gouze, E.: Dry atmospheric deposition and diazotrophy as sources of new nitrogen to northwestern Mediterranean oligotrophic surface waters, Deep-Sea Res. Pt. I, 54, 1859-1870, 2007.

Siokou-Frangou, I., Christaki, U., Mazzocchi, M. G., Montresor, M., Ribera d'Alcalá, M., Vaqué, D., and Zingone, A.: Plankton in the open Mediterranean Sea: a review, Biogeosciences, 7, 15431586, doi:10.5194/bg-7-1543-2010, 2010.

Spatharis, S., Skliris, N., Meziti, A., and Kormas, K.: First record of a Trichodesmium erythraeum bloom in the Mediterranean Sea: a result of climate change?, Can. J. Fish. Aquat. Sci., 69, 1444 1455, 2012. 
Tanaka, T., Zohary, T., Krom, M. D., Lawe, C. S., Pitta, P., and Psarra, S.: Microbial community structure and function in the Levantine Basin of the Eastern Mediterranean, Deep-Sea Res. I, 54, 1721-1743, 2007.

Tanaka, T., Thingstad, T. F., Christaki, U., Colombet, J., CornetBarthaux, V., Courties, C., Grattepanche, J.-D., Lagaria, A., Nedoma, J., Oriol, L., Psarra, S., Pujo-Pay, M., and Van Wambeke, F.: Lack of P-limitation of phytoplankton and heterotrophic prokaryotes in surface waters of three anticyclonic eddies in the stratified Mediterranean Sea, Biogeosciences, 8, 525-538, doi:10.5194/bg-8-525-2011, 2011.

Tanhua, T., Hainbucher, D., Cardin, V., Álvarez, M., and Civitarese, G.: Repeat hydrography in the Mediterranean Sea, data from the Meteor cruise 84/3 in 2011, Earth Syst. Sci. Data Discuss., 6, 59-71, doi:10.5194/essdd-6-59-2013, 2013.

Tanhua, T., Hainbucher, D., Schröder, K., Cardin, V., Álvarez, M., and Civitarese, G.: The Mediterranean Sea system: a review and an introduction to the special issue, Ocean Sci. Discuss., 10, 581617, doi:10.5194/osd-10-581-2013, 2013.

Thingstad, F. T., Zweifel, U. L., and Rassoulzadegan, F.: P limitation of heterotrophic bacteria and phytoplankton in the northwest Mediterranean, Limnol. Oceanogr., 43, 88-94, 1998.

Thingstad, T. F., Krom, M. D., Mantoura, R. F., Flaten, G. A., Groom, S., and Herut, B.: Nature of phosphorus limitation in the ultraoligotrophic Eastern Mediterranean, Science, 309, 10681071, 2005.
Tripp, H. J., Bench, S. R., Turk, K. A., Foster, R. A., Desany, B. A., Niazi, F., and Zehr, J. P.: Metabolic streamlining in an open-ocean nitrogen-fixing cyanobacterium, Nature, 464, 90-94, 2010.

Vaulot, D., Courties, C., and Partensky, F.: A simple method to preserve oceanic phytoplankton for flow cytometric analyses, $\mathrm{Cy}-$ tometry, 10, 629-635, 1989.

Wilson, S. T., Bottjer, D., Church, M. J., and Karl, D. M.: Comparative assessment of nitrogen fixation methodologies, conducted in the oligotrophic North Pacific Ocean, Appl. Environ. Microb., 78, 6516-6523, 2012.

Yogev, T., Rahav, E., Bar-Zeev, E., Man-Aharonovich, D., Stambler, N., Kress, N., Beja, O., Mulholland, M. R., Herut, B., and Berman-Frank, I.: Is dinitrogen fixation significant in the Levantine Basin, East Mediterranean Sea?, Environ. Microbiol., 13, 854-87, 2011.

Zehr, J. P. and Kudela, R. M.: Nitrogen cycle of the open ocean: from genes to ecosystems, in: Annual Review of Marine Science, Vol. 3, edited by: Carlson, C. A. and Giovannoni, S. J., 197-225, 2011.

Zehr, J. P. and Ward, B. B.: Nitrogen cycling in the ocean: New perspectives on processes and paradigms, Appl. Environ. Microb., 68, 1015-1024, 2002.

Zehr, J. P., Bench, S. R., Carter, B. J., Hewson, I., Niazi, F., Shi, T., and Affourtit, J. P.: Globally Distributed Uncultivated Oceanic N-2-Fixing Cyanobacteria Lack Oxygenic Photosystem II, Science, 322, 1110-1112, doi:10.1126/science.1165340, 2008. 